\title{
SOCIAL PROTECTION AND EMPLOYMENT IN AFRICA'S AGRICULTURAL SECTOR
}

\author{
Romanus OSABOHIEN 1,2 , Olaronke ONANUGA ${ }^{1,2}$, Busayo ADEROUNMU ${ }^{1}$, \\ Oluwatoyin MATTHEW ${ }^{1,2}$, Evans OSABUOHIEN ${ }^{1,2}$ \\ ${ }^{1}$ Department of Economics and Development Studies, Covenant University, Ota, Nigeria \\ ${ }^{2}$ Centre for Economic Policy and Development Research (CEPDeR), Covenant University, Ota, Nigeria
}

Received 19 January 2020; accepted 24 February 2020

\begin{abstract}
Social protection is increasingly becoming a powerful tool for enhancing productivity and employment and is, therefore, important for Africa's agricultural transformation. Thus, this study aims at examining how Africa's agricultural sector can be transformed through social protection policies and programmes for employment. It applies the Feasible Generalised Least Squares (FGLS) econometric method on a panel of 38 African countries with the data sourced from the Country Policy and Institutional Assessment (CPIA) and World Development Indicators (WDI) for the period 2005-2017. The results from the study show that social protection has a positive impact on employment outcomes through various channels such as building human resource, equity in the use of public resources, social inclusion, among others. The study concludes by recommending that the governments of African countries should implement effective social protection programmes and policies in the agricultural sector in form of insurance, in-kind and cash support, among others to make farming attractive, thereby increasing employment and productivity.
\end{abstract}

Keywords: agricultural transformation, farming, productivity.

JEL Classification: O47, E61, Q12.

\section{Introduction}

The exposure to risks, shocks and low welfare incentives are the main problems faced by agricultural households in Africa (Osabohien et al., 2020a, 2020b, 2020c; Matthew et al., 2019a, 2019b; Osabohien et al., 2019a, 2019b; Omiti \& Nyanamba, 2007). This is as a result of the fact that in Africa various policy and institutional reforms have been less than satisfactory in their outcomes (Beecroft et al., 2020; Igharo et al., 2020).

Also, social protection policies and programmes are recognised to be important weapons in elevating the welfare of households who are engaged in the agricultural sector as a means of livelihood, especially the most vulnerable segment of the population who live in rural communities (Matthew et al., 2019a, 2019b; Devereux, 2016). Agricultural transformation has been recognised to be a major catalyst to the development of African economies as a result of the challenges the continent is facing such as food insecurity, under-nourishment, youth unemployment and lack of engagement in international value chains These are the major reasons why agricultural transformation is highly important in
Africa (Allieu, 2019; Osabuohien et al., 2018; Van Kesteren, 2016).

Farmers in rural African communities are vulnerable to various risks and shocks, which tends to create high level of income insecurity and farmers' job-related health and safety. Efficient and effective implantation of social protection programmes and policies will no doubt help the most vulnerable farmers cope with related risks and shocks and contribute to the creation of better employment opportunities for rural workers and their households as shown by India's public work programmes (Matthew et al., 2019a, 2019b; Osabohien et al., 2019a, 2019b; Samson et al., 2015).

African farmers and agriculture are the major drivers of the continent's economic development; this is because, the agricultural sector is the largest employer of labour especially in rural areas (Osabohien et al., 2020a, 2020b, 2020c; Osabohien et al., 2018; Osabuohien et al., 2018; Aman et al., 2017; Matthew et al., 2020). Africa's agriculture needs a more transformation foundation for providing income and employment for a fast-growing population (Osabohien et al., 2018; Aman et al., 2017). African

${ }^{*}$ Corresponding author. E-mail: romanus.osabohien@covenantuniversity.edu.ng

This is an Open Access article distributed under the terms of the Creative Commons Attribution License (http://creativecommons.org/licenses/by/4.0/), which permits unrestricted use, distribution, and reproduction in any medium, provided the original author and source are credited. 
agricultural sector accounts for about $70 \%$ of employment, but many African countries are net food importers. The foundation for transforming the agricultural sector in Africa is to develop the rural areas. African countries have in the past neglected the rural and agricultural sectors while giving priority to the industrial and urban sectors. The contribution of agriculture to economic growth through the production of food, supply of raw materials to industries, employment generation, provision of market for goods and service sector amongst others cannot be adequately captured without emphasis to the rural sector (Matthew et al., 2018; Osabohien et al., 2020a, 2020b, 2020c).

One of the greatest socio-economic challenges in Africa is the lack of employment in the rural areas. Millions of rural Africans are currently unable to get themselves out of poverty. A number of policy briefings have been carried out on employment generation in rural areas, including the Brussels Development Briefing on Major Drivers for Rural Transformation in Africa: Job Creation for Rural Growth. The two key and related policy proposals made are the encouragement of small-scale farmers to work in harmony to increase their productivity and access to markets, and the increase in access to social protection. These policies were based on the estimate that an additional dollar income from farm jobs would generate an additional $\$ 0.5-\$ 0.6$ income in non-farm jobs in rural areas of Africa (Pye-Smith, 2012). Also, social protection is gaining prominence on the global development agenda as it is used to address global crises, like food prices, climate change, and so on, by reducing food insecurity and creating jobs for vulnerable households in developing countries across the globe (Tirivayi et al., 2013).

Food and Agricultural Organisation (FAO) Report of 2018 showed that agriculture accounts for 35\% (1.07 billion) of employment globally. Globally, the employment rate in the agricultural sector has been on a decline. There was about 20 percent decline from $70 \%$ to $50 \%$ between the 1980s and 2015 in agricultural sector employment in Africa and Asia. Agriculture is also one of the least paid job with little or no access to basic health services for its workers (FAO, 2018). The lack of prospect for good job, freedom of association and collective bargaining, reward for labour as well as the poor infrastructure associated with rural areas where most agricultural work is carried out make a good proportion of youth sceptical in entering the sector (International Labour Organisation - ILO, 2011).

In pursuance of using agriculture to create new employment opportunities in Africa, social protection programmes have been initiated and implemented by different stakeholders in Africa to improve the welfare of small-scale farmers (Al-Hassan \& Poulton, 2009). The policy of social protection and agriculture gained popularity in Africa since the African Fertilizer Summit, called by the African Union, held in Abuja, Nigeria, in 2006 (African Union, 2008; Druilhe \& Barreiro-Hurlé, 2012). To scale-up the benefits of social protection and agricultural development, the Ethiopian government linked its social protection programs called the Productive Safety Net Programme (PSNP) with its agricultural/rural development programme called Household Asset Building Programme (HABP) in 2009 (Cirillo et al., 2017). Malawi used the convergence between social protection and agriculture to ensure smallholders' access to agricultural inputs for crop diversification and food security (Devereux et al., 2008b). Hence, an association of stakeholders called the National Smallholder Farmers' Association of Malawi (NASFAM), which represents about 100,000 farmers, provides agricultural inputs at cheaper prices to its members.

The Association places the farmers in a stronger bargaining position when selling their produce and it encourages them to think as entrepreneurs and businessmen, rather than subsistence farmers (Phyo, 2018; Pye-Smith, 2012). The International Fund implements the agriculture projects with social protection programmes by the International Fund for Agricultural Development (IFAD) in African countries. These projects are primarily for people with marginal lands (for example; creation of small dams), rural women (for example; increased access to credit) and vulnerable groups, for example; improved seeds (Al-Hassan \& Poulton, 2009). Meanwhile, some African countries have not given social protection much attention because they believe it creates dependency and it is expensive. The Food and Agriculture Organisation (2015) had campaigned that social protection fosters farm and non-farm production activities and not dependency. However, a negative synergy has, also, been identified between social protection and agriculture. The Sasakawa Global 2000 social protection credit scheme in 1990s, in Ethiopia and Ghana, was prone to collapse due to production variability that disrupts reliable repayment- for example; drought, flood, among others, (Devereux et al., 2008a).

Though, Nigeria had agricultural subsidies and inputs, Holmes (2011) observed that they are not necessarily targeted at the poor. The Nigerian government spent a relatively low portion of its budget on the social sectors, compared to other sectors of the economy (HagenZanker \& Tavakoli, 2011). Due to the Debt Relief Gain (DRG) that was negotiated with the Paris Club in 2005, the Nigerian government was compelled to ensure propoor expenditure in its budget. In spite of the DRG, the overall expenditure on social protection in Nigeria remains relatively small (Holmes, 2011). Miroro and Van Kesteren (2016) support that, although social protection programmes have enhanced the resilience of vulnerable and poor people in Africa, they are inadequate to liberate people from poverty. This is because the poor are still vulnerable to losses from natural disasters and uncertain inputs and market failures, and lack of insurance due to low income. This contradiction has motivated this study to contribute to the literature and policy debate on social protection and agriculture by examining the role of social protection on agricultural employment in Africa.

The line of argument in this study is that since agricultural activities are done mainly in rural areas, social 
protection programmes and policies are required to make agriculture attractive to people to venture into. This help in controlling rural-urban migration, thereby enhancing the productive capacity of the sector, which will lead to food security in the long-run. The contribution of this study to the extant literature is that the study applied the Feasible Generalised Least Squares (FGLS) covering a wide-range of African countries which has not be applied in the context of the study of economic literature to the best knowledge of the authors. The study is organised in five sections. Following this introductory section is section two which presents some insights from the literature. Section three details the method engaged in the study; section four discusses the empirical analysis of the results and findings of the study; section five concludes by recommending policies that will boost agricultural production through social protection measures provided for the farmers.

\section{Literature review}

Social protection simply means policies and programme; for both the formal and informal sectors of the economy, which provides social assistance to poor individuals and households, especially those in rural communities who are more vulnerable to shocks and risks (Allieu, 2019; Osabohien et al., 2019; Matthew et al., 2019; Matthew et al., 2018; Devereux, 2016). The concept of social protection means the strategy for providing cash or in-kind supports to the less privileged, that are capable of protecting the vulnerable against risks and shocks, and it is also measure of a set of actions used in enhancing the control of stress faced by rural farmers, households and individuals in rural communities (FAO, 2015).

Few studies (e.g. Todd et al., 2009; IEG, 2011; Gertler et al., 2012) in the literature have shown that social protection leads to a significant increase in agricultural investment, employment and production (like livestock ownership, farm tools, land ownership, and so on). Evidence of this was obtained under the cash transfers programme in Latin America (Omiti \& Nyanamba, 2007). The same findings were also obtained for some African countries (for example, Ethiopia, Lesotho, Malawi and Zambia) (Devereux et al., 2008a; Covarrubias et al., 2012; Berhane et al., 2011; AIR, 2013; Boone et al., 2013). Although, Andersson et al., (2009) supports Devereux et al. (2008a) that social protection increases agricultural employment, production and investments in Ethiopia, Andersson et al. (2009) found that social protection did not increase livestock ownership; it increased the number of trees planted in Ethiopia.

Asfaw et al. (2012), on the other hand, found that social protection simply leads to a modest increase in investments in Kenya. Handa et al. (2013) proved that social protection has no significant impact on investments in Ghana. Aside from investment, the size, duration, and cash transfers of social protection programme are found to have significant effect on local food prices in Niger and
Uganda (Save the Children, 2009; Creti, 2010). The opposite was observed for Swaziland and Zambia (Creti, 2010; Tirivayi et al., 2013). Holmes (2011) addressed the effectiveness of social protection in addressing poverty and inequality in Nigeria. Social protection (the debt relief gain (DRG) and the National Social Insurance Trust Fund) in Nigeria fell short in meeting the needs of the poor.

Miroro and Van Kesteren (2016) found that the linking of agricultural and social protection interventions offers complementary benefits in Ethiopia by ensuring higher food security and increase in non-farm business activities. This is in line with the FAO (2015) report on social protection and agriculture that social protection is a means of reducing poverty and food insecurity as well as gives more opportunities for both farm and non-farm work. Nehring (2012) examined the linkage between social protection and agricultural production in Mexico. Using food subsidies and cash transfer as a measure of social protection which aims at providing access to social services as well as cash for immediate consumption with focus on the less privileged population. Slater and McCord (2009) examined the linkage between social protection and rural development with particular reference to the Low-Income Countries. The study explored the nature of intervention, value and duration to the local economy among others and showed that social protection inventions exhibited limited impact on economic growth on the aggregate.

African Enterprise Challenge Fund (AECF) (2017) examined the effect of agribusiness on creation of decent work in Africa using the changes that occurs in beneficiary income, the percentage of employment provided through the funding and the associated wage. The growing concern in achieving decent work, which is the $8^{\text {th }}$ goal of Sustainable Development, prompted the intervention to compensate for growth through the provision of social protection programmes. There has been increased recognition that social protection programmes are means of reducing prevalence and incidence of poverty in most developing countries. These programmes that which increases production is not only constrained to the beneficiary alone but its impact cut across various countries, which embraces inclusive growth (FAO, 2018).

\section{Methodological approach}

\subsection{The empirical model}

Before building the model, theories of welfare related to the study are briefly reviewed. The Kaldor-Hicks compensation criterion was adopted for the study. The KaldorHicks theory is known as the new welfare economics theory accepting the Pareto's ordinal measurement of utility and the impossibility of its interpersonal comparisons (Stiglitz, 2012). This theory opined that an improvement in welfare of households in the society through employment and social good can be regarded as welfare even in the case of increasing the employment of at least one household and should not reduce the employment and 
welfare of other households in the society (Stringham, 2001; Stavins et al., 2003). The main reason for adopting the Kaldor-Hicks criterion is that the theory is based on the assumption that in a society, people's satisfaction is mutually exclusive; meaning that, individuals satisfaction derived from public good is independent from the other (Stringham, 2001). Therefore, based on Kaldor-Hicks theory, the implicit form of the model is specified in equation (1) as:

$$
A E M P_{i t}=f\left(S O P_{i t}, P O P_{i t}\right) .
$$

Equation (1) specifies the panel model in its implicit form which is estimated using the feasible generalised least squares (FGLS) on the basis that there is no simultaneous causality between the endogenous and the exogenous variables in the model and there is a long-run relationship existing between them. Insight of this model was derived from the empirical works of Daidone et al. (2017) and Jones et al. (2017), that examined the relationship between social protection and agriculture applying the propensity score matching (PSM) approach, the contribution of this study to the extant literature is that the study applied the Feasible Generalised Least Squares (FGLS) covering a wide-range of African countries which has not be applied in the context of the study of economic literature to the best knowledge of the authors.

From equation (1), $A E M P$ is agricultural employment (the dependent variable), SOP represents social protection (the key variable) and $P O P$ represents population (urban and rural) as the control variable. Four social protection variables are included in the model, as shown in equation (2), the explicit form of the model. The variables are in their $\log$ form to bring all the variables in the same unit of measure and ensure that the estimates are Best Linear Unbiased Estimator - BLUE (Ejemeyovwi et al., 2018).

$$
\begin{aligned}
& \log A E M P_{i t}=\alpha_{0}+\alpha_{1} \log B H R_{i t}+\alpha_{2} \log E P R_{i t}+ \\
& \alpha_{3} \log P F S E_{i t}+\alpha_{4} \log S O P R_{i t}+\alpha_{5} \log R P O P_{i t}+ \\
& \alpha_{6} \log U P O P_{i t}+e_{i t} .
\end{aligned}
$$

From explicit form of the model in equation (2): Where AEMP is agriculture employment (\% of total employment), $B H R$ is building human resources, $E P R$ is equity of public resource use, PFSI is policy for inclusion and equity, RPOP is rural population and UPOP is urban population. $\alpha_{0}$ is constant term; $\alpha_{1}, \alpha_{2}, \alpha_{3}, \alpha_{4}, \alpha_{5}$ and $\alpha_{6}$ are the parameters of the explanatory variables in the model. The a priori expectation is that the estimated coefficient explanatory variables should be positively related to agricultural employment, except urban population, this can be expressed mathematically as: $\alpha_{1}>0, \alpha_{2}>0, \alpha_{3}>$ $0, \alpha_{4}>0, \alpha_{5}>0, \alpha_{6}<0 . e$ is the error term representing other important explanatory variables not included in the model due to paucity and to avoid high incidence of multicollinearity among the explanatory variables.

The line of argument is that since agricultural activities are done mainly in rural areas, social protection programmes are required to make agriculture attractive to people to venture into. This help in controlling rural-urban migration, thereby enhancing the productive capacity of the sector, which will lead to food security in the long-run. In the model, $i$ represent entities. Entities in the context of this study represents the 38 African countries employed in the study which are: Angola, Benin, Burkina Faso, Burundi, Cameroon, Cape Verde, Central African Republic, Chad, Comoros, Congo Democratic Republic, Congo, Cote d'Ivoire, Djibouti, Ethiopia, Gambia, Ghana, Guinea, Guinea Bissau, Kenya, Lesotho, Liberia, Madagascar, Malawi, Mali, Mauritania, Mozambique, Niger, Nigeria, Rwanda, Senegal, Sierra Leone, South Sudan, Sudan, Tanzania, Togo, Uganda, and Zambia. The justification or the reason for the choice of these countries is hinged on the fact that those are the African countries listed in Country Policy Institutional Assessment (CPIA) social protection of the World Bank IDA (International Development Association) of which data is available.

Also, in the model, $t$ represents time. Time in the context of our study represents the 13 years (2005-2017) period, multiplied by 38 countries, making it a total of 499 observations. Each of the variables in the model is logged so as to bring them to the same base (unit of measurement), ensure a best outcome and reduce any level of the incidence of heteroscedasticity (ensuring that the classical assumption of the ordinary least squares are not violated) in the model (Ejemeyovwi et al., 2018; A.T. Onanuga \& O. T. Onanuga, 2016; Olokoyo et al., 2009).

\subsection{Variable description}

Data for this study was sourced from the World Bank two main data base- World Development Indicators (WDI) and the Country Policy and Institutional Assessment (CPIA). Agriculture employment and population were sourced from the WDI, while social protection variables were sourced from CPIA.

The CPIA rates countries against a set of 16 criteria categorised into four major clusters; which are; (i) economic management; (ii) structural policies; (iii) policies for social inclusion and equity; and (iv) public sector management and institutions. The criteria are focused on balancing the capture of the key factors that foster employment creation, growth and poverty reduction (Anderson \& Valdés, 2008). The CPIA for Africa which explains the rate at which African countries are progressing in terms of strengthening the quality of their policies and institutions capable of creating employment and reduce poverty among the most vulnerable. CPIA data is in rating $(1=$ low to $6=$ high) - for all countries listed in World Bank IDA. Thus, the variables used in the study are presented herein:

Agricultural Employment (AEMP): employment in agriculture in the context of our study refers to individuals who are engaged in any activity related to agriculture which is made of hunting, crop farming, forestry and fishing among other agricultural related activities, this is measured as a percentage (\%) of total employment modelled international labour organisation (ILO) estimate, 
used as the dependent variable and was sourced from the WDI.

Building Human Resources (BHR): Building human resources assesses the national policies and public and private sector service delivery that affect the access to and quality of household health and educational services, including prevention and treatment of diseases such as tuberculosis, malaria etc. This was sourced from CPIA.

Equity in the use of public Resource (EPR): Equity of public resource use assesses the extent to which the pattern of public expenditures and revenue collection affects the poor and is consistent with employment creation and national poverty reduction priorities. Sourced from CPIA.

Policy for social inclusion and equity (PFSIE): The policies for social inclusion and equity include gender equality, equity of public resource use, building human resources, social protection and labour, and policies and institutions for environmental sustainability. Sourced from CPIA.

Social Protection Ratings (SOPR): The overall social protection ratings is social protection and labour assess government policies in social protection and labour

Table 1. Summary of statistics (source: Authors' computation, 2019 using E-views 10)

\begin{tabular}{|l|c|c|c|c|}
\hline \multicolumn{1}{|c|}{ Variable } & Mean & $\begin{array}{c}\text { Standard } \\
\text { Deviation }\end{array}$ & Minimum & Maximum \\
\hline $\begin{array}{l}\text { Agriculture } \\
\text { Employment }\end{array}$ & 58.76 & 21.28 & 1.63 & 91.84 \\
\hline $\begin{array}{l}\text { Building Human } \\
\text { Resource }\end{array}$ & 3.40 & 0.613 & 1.00 & 4.50 \\
\hline $\begin{array}{l}\text { Equity of public } \\
\text { resource use }\end{array}$ & 3.25 & 0.67 & 1.00 & 4.50 \\
\hline $\begin{array}{l}\text { Policy for social } \\
\text { inclusion }\end{array}$ & 3.19 & 0.49 & 1.5 & 4.30 \\
\hline $\begin{array}{l}\text { Social protection } \\
\text { rating }\end{array}$ & 3.00 & 0.56 & 1.00 & 4.50 \\
\hline Rural population & 1.44 & 1.91 & 18202 & 96407 \\
\hline $\begin{array}{l}\text { Urban } \\
\text { Population }\end{array}$ & 3.89 & 1.26 & 5.23 & 5.68 \\
\hline
\end{tabular}

Note: Variables are in their log form. market regulations that reduce the risk of becoming poor, assist those who are poor to better manage further risks, and ensure a minimal level of welfare to all people. Sourced from the CPIA of the World Bank.

Rural Population (RPOP): Rural population measured as a percentage (\%) of total population refers to people living in rural areas as defined by national statistical offices. It is calculated as the difference between total population and urban population. Sourced from the WDI.

Urban Population (UOP): Rural population measured as a percentage (\%) of total population refers to people living in urban areas or cities as defined by national statistical offices. Sourced from the WDI.

\section{Results}

This section of the study presents the results obtained from the econometric analysis. The starting point of the presentation of the results is the presentation of the summary statistics of the variables. The descriptive or summary statistics of the variable presented in Table 1 shows the mean, standard deviation, minimum and maximum values of the variables. There is no outlier in the collected data. Therefore, the Fisher's panel unit root test is applied to the log transformation of the data and presented in $\mathrm{Ta}$ ble 2 .

From the Fisher's unit root test conducted as shown in Table 2, the agricultural employment, rural and urban population are stationary at level. Other variables are stationary at first difference that is at $1 \%$ level of significance, except for building human resources $(\log B H R)$, which is significant at $5 \%$.

To ensure that the estimated results are not spurious, pre-estimation tests were conducted to identify whether a static (like FGLS) or dynamic estimation method is applicable. Table 3 presents the causality test results between the dependent variable and the explanatory variables. There is no simultaneous causality between the dependent variable and the independent variables. Hence, there is no suspicion of endogeneity in the specified model.

The cointegration test results showed the null hypothesis of no long-run relationship in the specified model is

Table 2. Fisher (Augmented Dickey Fuller) panel unit root test(source: authors' computation 2019 using E-views 10)

\begin{tabular}{|c|c|c|c|c|c|}
\hline Variable & Inverse chi-square & Inverse normal & Inverse logit & $\begin{array}{l}\text { Modified inv. } \\
\text { Chi-square }\end{array}$ & Decision \\
\hline Agriculture employment & $160.03^{* * *}$ & $-2.70^{\star * *}$ & $-4.55^{\star * \star}$ & $7.07^{\star * *}$ & $\mathrm{I}(0)^{\star \star \star}$ \\
\hline Building human resources & $102.35^{\star \star}$ & $-2.98^{\star *}$ & $-3.52^{\star * *}$ & $2.33^{\star * *}$ & $\mathrm{I}(1)^{\star \star}$ \\
\hline Equity of public resource & $136.94^{* * *}$ & $-7.47^{\star * *}$ & $-7.77^{\star * *}$ & $5.17^{\star \star *}$ & $\mathrm{I}(1)^{\star * *}$ \\
\hline Policy for social inclusion & $120.96^{* * *}$ & $-2.90^{\star * *}$ & $-3.21^{\star * *}$ & $3.86^{\star * *}$ & $\mathrm{I}(1)^{\star * *}$ \\
\hline Social protection ratings & $373.49^{\star * *}$ & $-12.22^{\star * *}$ & $-20.76^{\star * *}$ & $24.61^{\star * *}$ & $\mathrm{I}(1)^{\star * \star}$ \\
\hline Rural population & $235.61^{* * *}$ & $-4.18^{\star \star *}$ & $-9.96^{\star * *}$ & $13.28^{\star * *}$ & $\mathrm{I}(0)^{\star \star *}$ \\
\hline Urban Population & $447.19^{* * *}$ & $-10.58^{\star \star \star}$ & $22.64^{* * *}$ & $30.67^{\star * *}$ & $\mathrm{I}(0)^{\star \star \star}$ \\
\hline
\end{tabular}

Note: ${ }^{* *}$ and ${ }^{* * *}$ indicate $5 \%$ and $1 \%$ level of significance respectively. The Variables are used in their logarithmic transformed form (to make them more comparative and reduce the issue of heteroscedasticity (A. Onanuga \& O. T. Onanuga, 2016; Olokoyo et al., 2009) 
rejected for the alternate hypothesis at 5\% level of significance. Based on the non-existence of simultaneous causality and the existence of long-run relationship, the study estimated the model with the Feasible Generalised Least Squares (FGLS) which is presented in Table 4.

Table 3. Panel Granger causality test (source: authors' computation, 2019 using E-views 10)

\begin{tabular}{|l|c|c|}
\hline \multicolumn{1}{|c|}{ Null Hypothesis } & F-Statistic & Probability \\
\hline $\begin{array}{l}\log B H R \text { does not Granger Cause } \\
\log A E M P\end{array}$ & 1.2325 & 0.2927 \\
\hline $\begin{array}{l}\log A E M P \text { does not Granger Cause } \\
\log B H R\end{array}$ & 0.2571 & 0.7734 \\
\hline $\begin{array}{l}\log E P R \text { does not Granger Cause } \\
\log A E M P\end{array}$ & 0.6924 & 0.5010 \\
\hline $\begin{array}{l}\log A E M P \text { does not Granger Cause } \\
\log E P R\end{array}$ & 0.4875 & 0.6145 \\
\hline $\begin{array}{l}\log P F S I \text { does not Granger Cause } \\
\log A E M P\end{array}$ & 1.2914 & 0.2760 \\
\hline $\begin{array}{l}\log A E M P \text { does not Granger Cause } \\
\log P F S I\end{array}$ & 0.3595 & 0.6982 \\
\hline $\begin{array}{l}\log S O P R \text { does not Granger Cause } \\
\log A E M P\end{array}$ & 0.3294 & 0.7195 \\
\hline $\begin{array}{l}\log A E M P \text { does not Granger Cause } \\
\log S O P R\end{array}$ & 4.0413 & $0.0183^{\star *}$ \\
\hline $\begin{array}{l}\log A E M P \text { does not Granger Cause } \\
\log P O P\end{array}$ & 0.0642 & 0.9378 \\
\hline $\begin{array}{l}\log R P O P \text { does not Granger Cause } \\
\log A E M P\end{array}$ & 1.0515 & 0.3504 \\
\hline $\begin{array}{l}\log A E M P \text { does not Granger Cause } \\
\log R P O P\end{array}$ & 0.5850 & 0.5575 \\
\hline $\begin{array}{l}\log U P O P \text { does not Granger Cause } \\
\log A E M P\end{array}$ & 0.5448 & 0.5804 \\
\hline $\begin{array}{l}\log A E M P \text { does not Granger Cause } \\
\log U P O P\end{array}$ & 0.8238 & 0.4395 \\
\hline
\end{tabular}

Note: ${ }^{* *}$ means coefficient is significant at $5 \%$ level.

For robustness, correcting for heteroscedasticity alone and heteroscedasticity and autocorrelation specify FGLS. When no autocorrelation is assumed, all the variables, except building human resources (BHR), are significant. Equity in the use of public resources (EPR), social protection ratings (SOPR) and increase in rural population significantly increase agricultural employment. Social protection for inclusion and equity (PFSIE), and urban population (UPOP) significantly reduce agricultural employment.

When both heteroscedasticity and autocorrelation are corrected in FGLS estimate, coefficients of rural population and urban population are significant at $1 \%$. Increasing rural population increases agricultural employment while decreasing urban population decreases agricultural employment. This supports the migration of population from the rural area to the urban area to search for blue and white-collar jobs. The Wald Chi-square test rejects the null hypothesis that the coefficients are equal to zero. This indicates that removing any of the variables from the model will substantially harm the fit of the specified model.

As countries seek for development, agricultural output increases, unlike productivity in the informal sector as observed by Samson et al. (2015). However, the problems faced by African farmers is the lack of appropriate social protection programmes needed to increase employment and productivity, and governments play a very crucial role in raising employment and productivity through social protection programmes. This is based on the result obtained in the study; from the FGLS result (see Table 4 ), it showed that $1 \%$ increase in overall social protection all things been equal, has the potential of increasing agriculture employment by approximately $0.22 \%$, in the same way, equity in public resource use tend to increase employment by $0.79 \%$, rural population increased employment by $0.28 \%$, urban population reduced agricultural employment by $0.30 \%$. The negative relationship between urban population and agricultural employment is not surprising, because, most of the agricultural activities are been carried out in rural areas, therefore linking social protection to agriculture, especially in the rural areas is required to make rural agriculture a cool business to control rural-urban migration.

The findings of this study are somewhat related to the findings of Croppenstedt, Knowles, and Lowder (2018)

Table 4. Feasible generalised least squares (source: authors' computation, 2019)

\begin{tabular}{|c|c|c|c|c|c|}
\hline \multicolumn{3}{|c|}{ Corrected for Heteroscedasticity alone } & \multicolumn{3}{|c|}{$\begin{array}{l}\text { Corrected for Heteroscedasticity } \\
\text { \& Autocorrelation }\end{array}$} \\
\hline Variables & Coefficients & t-Statistics & Variables & Coefficients & $\mathrm{t}$-Statistics \\
\hline $\log B H R$ & 0.0273 & 0.24 & $\log B H R$ & 0.0401 & 1.18 \\
\hline $\log E P R$ & $0.7918^{\star * *}$ & 8.04 & $\log E P R$ & 0.0207 & 0.61 \\
\hline $\log P F S I$ & $-0.9994^{\star * \star}$ & -9.30 & $\log$ PFSI & -0.0399 & -0.54 \\
\hline $\log S O P R$ & $0.2154^{\star *}$ & 2.05 & $\operatorname{logSOPR}$ & 0.0113 & 0.44 \\
\hline $\log R P O P$ & $0.2895^{\star * *}$ & 13.99 & $\log \mathrm{RPOP}$ & $0.2930^{* * *}$ & 12.58 \\
\hline $\log U P O P$ & $-0.3098^{\star \star \star}$ & -16.87 & $\log \mathrm{UPOP}$ & $-0.2869^{\star \star \star}$ & -13.75 \\
\hline Constant & $5.6839^{\star * *}$ & 36.49 & Constant & $4.1451^{\star * *}$ & 23.70 \\
\hline Wald $\mathrm{Chi}^{2}$ & $710.09^{* * *}$ & & Wald $\mathrm{Chi}^{2}$ & $231.06^{* * *}$ & \\
\hline
\end{tabular}

Note: ${ }^{\star \star}$ and ${ }^{\star * \star}$ indicate $5 \%$ and $1 \%$ level of significance. 
where it was found that social protection has positive welfare impact on agricultural household, also stimulating agricultural employment and productivity as obtained in this study that overall social protection increased employment by $21.54 \%$. Most of the farmers in Africa lives in rural communities and are poor; therefore, social protection is highly essential to prevent them from sinking further into poverty. In line with the findings of Samson et al. (2015) that posited that social protection has positive impacts on employment outcomes through several channels such as human capital development, changes in household labour allocation, working conditions. It was also pointed that social protection has the power of increasing rural wages, as shown by India's public works programmes.

This study has taken the findings of Samson et al. (2015) further in terms of the channels through which social protection positively impact on employment outcomes which was considered in this study such as building human capital, equity of public resource use, policy for social inclusion and equity. Similarly, Daidone et al. (2018) using the difference - in-difference approach pointed out that Ethiopian Productive Safety Net (PSN) social protection programmes has a positive impact on food security, this is done through increasing agricultural employment and productivity thereby increasing welfare and food security. Again, social protection can increase agricultural employment. Social protection programmes can also support asset accumulation in the form of livestock, land or otherwise, thereby enhancing productive capacity and potential income diversification, which in turn can trigger new opportunities for farm and non-farm employment.

This study disagrees with the findings of Matthew et al. (2019) pointing out that in ECOWAS agriculture do not necessarily lead to poverty reduction as a result of the fact that farming households in ECOWAS region are majorly peasant farmers and do not produce enough to sell. In our study, as divergence to Matthew et al. (2019) that focused only on agricultural investment and agricultural employment, ignoring the potential of social protection in agriculture. We argued that; though, social protection may not have a direct effect on poverty reduction, it has effect through different channels such as increasing employment among other channels.

\section{Conclusions}

The motivation for this study stemmed from the fact that Africa's agricultural workforce needs to be secured for the generation of rural employment. Therefore, agricultural social protection should focus on the enhancement of rural households access to mechanisation services, enhance rural households access to quality and affordable agricultural inputs; for example, delivery of quality fertiliser and seedlings, increase in the efficient delivery of water resources and management systems including irrigation, increase households welfare incentives such as medical care services among others.
The study made use of secondary data sourced from the country policy and institutional assessment and the World Development of the World Bank for the period 2005-2015 for 38 African countries. The study applied the feasible generalised squares and results obtained from the analysis showed that a $1 \%$ increase in overall social protection all things been equal, has the potential of increasing agriculture employment by approximately $0.22 \%$, in the same way, equity in public resource use tend to increase employment by $0.79 \%$, rural population increased employment by $0.28 \%$, urban population reduced agricultural employment by $0.30 \%$. The negative relationship between urban population and agricultural employment is not surprising, because, most of the agricultural activities are been carried out in rural areas, therefore linking social protection to agriculture, especially in the rural areas is required to make rural agriculture a cool business to control rural-urban migration.

Based on the findings, the study concluded by recommending that the governments of African countries should provide social protection in form of soft loans for farmers in rural communities to enable them buy modern farm implements like tractors, harvesters, ploughing machines and other farm implements needed to ease farming. In addition, the African governments should provide fertilizers to the farmers at subsidised rates. The governments should provide social and infrastructural facilities (such as provision of electricity, water, communication facilities, good roads, hospitals, schools and so on) in the rural areas, this will help reduce the rate at which people, especially the youths, leave the villages for the cities. As suggestion for future research in this area, there will be the need to conduct analysis using rural household level data to ascertain the extent to which social protection impact on poverty reduction and households' welfare in Africa.

\section{Acknowledgements}

Publication support received from Covenant University Centre for Research, Innovation and Discovery (CUCRID) is highly appreciated. The first draft of this paper was presented at the United Nations University World Institute for Development Economics Research (UNUWIDER) International Conference on "Transforming economies - for better jobs" in partnership with the United Nations Economic and Social Commission for Asia and the Pacific (UNESCAP), which held between 11th and 13th September 2019, in Bangkok, Thailand. Contributions from the conference participants and travel support received from the UNU-WIDER are highly appreciated. This paper was also presented at the first International Conference on African Entrepreneurship and Innovation (ICAEI, 2019) which held between 13th-14th June, 2019, in De Montfort University Leicester, United Kingdom. Contributions from the conference participants are appreciated as well.

The authors appreciate the Equipment Subsidy Grant awarded by the Alexander von Humboldt Foundation 
[REF: 3.4-8151/19047] to Centre for Economic Policy and Development Research (CEPDeR), Covenant University that facilitated the revision of the paper.

\section{References}

Africa Enterprise Challenge Fund (AECF). (2017). Creating opportunities for decent work in the AECF's agribusiness portfolio. Published by the African Union.

African Union. (2008, 27-31 October). Social policy framework for Africa. First Session of the AU Conference of Ministers in Charge of Social Development. Namibia.

Aman, M. G., Findling, R. L., Hardan, A. Y., Hendren, R. L., Melmed, R. D., Kehinde-Nelson, O., Hsu, H. A., Trugman, J. M., Palmer, R. H., Graham, S. M., \& Gage, A. T. (2017). Safety and efficacy of memantine in children with autism: Randomized, placebo-controlled studyand open-label extension. Journal of Child and Adolescent Psychopharmacology, 1, 27(5), 403-412. https://doi.org/10.1089/cap.2015.0146

American Institutes for Research (AIR). (2013). Zambia's Child Grant Program: 24-month impact report. Washington, DC.

Anderson, K., \& Valdés, A. (2008). Distortions to agricultural incentives in Latin America. World Bank.

https://doi.org/10.1596/28190

Andersson, C., Mekonnen, A., \& Stage, J. (2009). Impacts of the productive safety net program in Ethiopia on livestock and tree holdings of rural households. Journal of Development Economics, 94(2011), 119-126.

https://doi.org/10.1016/j.jdeveco.2009.12.002

Asfaw, S., Davis, B., Dewbre, J., Federighi, G., Handa, S., \& Winters, P. (2012). The impact of the Kenya CT-OVC Programme on productive activities and labour allocation. Paper prepared for the From Protection to Production project. UN Food and Agriculture Organization.

Al-Hassan, R., \& Poulton, C. (2009). Agriculture and social protection in Ghana. FAC Working Paper No. SP04. Future Agriculture Consortium, Brighton.

Allieu, A. M. (2019, 27 February). Implementing nationally appropriate social protection systems and measures for all: gaps and challenges facing rural area. A presentation at the UN DESA Expert Group Meeting on Eradicating Rural Poverty to implement the 2030 Agenda for Sustainable Development. Addis Ababa.

Beecroft, I., Osabuohien, E. S., Efobi, U. R., Olurinola, I., \& Osabohien, R. A. (2020). Manufacturing export and ICT infrastructure in West Africa: investigating the roles of economic and political institutions. Institutions and Economies, 1-36.

Berhane, G., Hoddinott, J., Kumar, N., \& Taffesse, A. S. (2011). The impact of Ethiopia's productive safety nets and household asset building programme: 2006-2010. International Food Policy Research Institute.

Boone, R., Covarrubias, K., Davis, B., \& Winters, P. (2013). Cash transfer programs and agricultural production: The case of Malawi. Agricultural Economics, 44, 365-378. https://doi.org/10.1111/agec.12017

Cirillo, C., Gyori, M., \& Soares, F. V. (2017). Targeting social protection and agricultural interventions: potential for synergies. International Policy Centre for Inclusive Growth. https://doi.org/10.1016/j.gfs.2016.08.006

Covarrubias, K., Davis, B., \& Winters, O. (2012). From protection to production: productive impacts of the Malawi social cash transfer scheme. Journal of Development Effectiveness, 4(1), 50-77. https://doi.org/10.1080/19439342.2011.641995
Creti, P. (2010). The impact of cash transfers on local markets: A case study of unstructured markets in Northern Uganda. Cash Learning Partnership.

Croppenstedt, A., Knowles, M., \& Lowder, S. K. (2018). Social protection and agriculture: Introduction to the special issue. Global Food Security, 16, 65-68. https://doi.org/10.1016/j.gfs.2017.09.006

Daidone, S., Davisa, B., Dewbrea, J., Migueleza, B., Niangb, O., $\&$ Pellerano, N. (2017). Linking agriculture and social protection for food security: The case of Lesoto. Global Food Security, 12, 146-154. https://doi.org/10.1016/j.gfs.2016.12.002

Devereux, S. (2016). Social protection for enhanced food security in sub-Saharan Africa. Food Policy, 60, 52-62. https://doi.org/10.1016/j.foodpol.2015.03.009

Devereux, S., Sabates-Wheeler, R., Guenther, B., Dorward, A., Poulton, C., \& Al-Hassan, R. (2008a). Linking social protection and support to small farmer development. Food and Agriculture Organisation (FAO). Rome.

Devereux, S., Sabates-Wheeler, R., Slater, R., Tefera, M., Brown, T., \& Teshome, A. (2008b). Ethiopia's PSNP: 2008 assessment report. Institute of Development Studies, University.

Druilhe, Z., \& Barreiro-Hurlé, J. (2012). Fertilizer subsidies in sub-Saharan Africa. ESA Working paper No. 12-04. Food and Agriculture Organisation, Rome.

Ejemeyovwi, J. O., Osabuohien, E. S., \& Osabohien, R. (2018). Investment in technology and human capital development in ECOWAS. International Journal of Economics and Business Research, 15(4), 463-474. https://doi.org/10.1504/IJEBR.2018.092151

Food and Agricultural Organisation - FAO. (2018). Agricultural trade and decent rural employment. Rural Transformations Information Note \#7.

Gertler, P. J., Martinez, S. W., \& Rubio-Codina, M. (2012). Investing cash transfers to raise long-term living standards. AEJ: Applied Economics, 4(1), 164-192.

https://doi.org/10.1257/app.4.1.164

Hagen-Zanker, J., \& Tavakoli, H. (2011). Fiscal space for social protection in Nigeria. ODI Project Briefing 61. Overseas Development Institute, London.

Handa, S., Park, M., Darko, R., Osei-Akoto, I., Davis, B., \& Daidone. S. (2013). Livelihood empowerment against poverty impact evaluation. Carolina Population Center, University of North Carolina, North Carolina. https://doi.org/10.23846/OW31075

Holmes, T. J. (2011). The diffusion of Wal-Mart and economies of density. Econometrica, 79(1), 253-302.

https://doi.org/10.3982/ECTA7699

Igharo, A. E., Osabohien, R., Onyemariechi, G. O., \& Ibidapo, D. T. (2020). Monetary policy transmission mechanism, the innovative banking system and economic growth dynamics in Nigeria. International Journal of Business Innovation and Research, 21(1), 1-22. https://doi.org/10.1504/IJBIR.2020.104032

Independent Evaluation Group - (IEG). (2011). Evidence and lessons learned from impact evaluations on social safety nets. World Bank, Washington DC.

International Labour Organisation. (2011). Rural development through decent work. Agriculture: An Engine of Pro-Poor Rural Growth. Rural Policy Brief, ILO, Geneva.

Jones, N., Holmesa, R., Presler-Marshallb, E., \& Stavropouloua, M. (2017). Transforming gender constraints in the agricultural sector: The potential of social protection programmes. Global Food Security, 12, 89-95. https://doi.org/10.1016/j.gfs.2016.09.004 
Matthew, O., Osabohien, R., Urhie, E., Ewetan, O., Adediran, O., Oduntan, E., \& Olopade, C. (2019a). Agriculture as a stimulant for Sustainable Development in ECOWAS. Sustainability: The Journal of Record, 12(4), 215-225. https://doi.org/10.1089/sus.2018.0039

Matthew, O. A., Osabohien, R., Ogunlusi, T. O., \& Edafe, O. (2019b). Agriculture and social protection for poverty reduction in ECOWAS. Cogent Arts and Humanities, 6, 1682107. https://doi.org/10.1080/23311983.2019.1682107

Matthew, O., Osabohien, R., Fagbeminiyi, F., \& Fasina, A. (2018). Greenhouse gas emissions and health outcomes in Nigeria: Empirical insight from Auto-regressive Distribution Lag technique. International Journal of Energy Economics and Policy, 8(3), 43-50.

Matthew, O. A., Ufua, D. E., Osabohien, R., Olawande, T., \& Edafe, O. D. (2020). Addressing unemployment challenge through micro and small enterprises (MSEs). Problems and Perspectives in Management, 18(2), 79-89.

https://doi.org/10.21511/ppm.18(2).2020.08

Miroro, O., \& Van Kesteren, F. (2016). The importance of social protection for Africa's agricultural transformation. INCLUDE. http://includeplatform.net/downloads/importance-socialprotection-africas-agricultural-transformation/

Nehring, R. (2012). Linking social protection and agricultural production: the case of Mexico. The International Policy Centre for Inclusive Growth Research brief 21.

Olokoyo, F. O., Osabuohien, E. S., \& Salami, A. O. (2009). An econometric analysis of foreign reserves and some macroeconomic variables in Nigeria (1970-2007). African Development Review, 21(3), 454-475.

https://doi.org/10.1111/j.1467-8268.2009.00218.x

Omiti, J., \& Nyanamba, T. (2007). Using social protection policies to reduce vulnerability and promote economic growth in Kenya. Futures Discussion Paper, 12.

Onanuga, A. T., \& Onanuga, O. T. (2016). Do financial and trade openness lead to financial sector development in Nigeria? $\mathrm{Za}$ greb International Review of Economics and Business, 19(2), 57-68. https://doi.org/10.1515/zireb-2016-0008

Osabohien, R., Afolabi, A., \& Godwin, A. (2018a). An econometric analysis of food security and agricultural credit facilities in Nigeria. The Open Agriculture Journal, 12(1), 227-239. https://doi.org/10.2174/1874331501812010227

Osabohien, R., Osabuohien, E., \& Urhie, E. (2018b). Food security, institutional framework, and technology: examining the Nexus in Nigeria using ARDL approach. Current Nutrition and Food Science, 14(2), 154-163. https://doi.org/10.2174/1573401313666170525133853

Osabohien, R., Matthew, O., Gershon, O., Ogunbiyi, T., \& Nwosu, E. (2019a). Agriculture development, employment generation and poverty reduction in West Africa. The Open Agriculture Journal, 13, 82-89.

https://doi.org/10.2174/1874331501913010082

Osabohien, R., Matthew, A. O., Aderounmu, B., \& Olawande, T. (2019b). Greenhouse gas emissions and crop production in West Africa: Examining the mitigating potential of social protection. International Journal of Energy Economics and Policy, 9(1), 57-66.

Osabohien, R., Osuagwu, E., Osabuohien, E., Ekhator-Mobayode, U. E., Matthew, O., \& Gershon, O. (2020a). Household access to agricultural credit and agricultural production in Nigeria: A propensity score matching model. South African Journal of Economic and Management Sciences, 22(1), a2688. https://doi.org/10.4102/sajems.v23i1.2688

Osabohien, R., Awolola, D. O., Matthew, O., Itua, Q. O., \& Elomien, E. (2020b). Foreign direct investment inflow and employment relation in Nigeria. Investment Management and Financial Innovations, 17(1), 77-84.

https://doi.org/10.21511/imfi.17(1).2020.07

Osabohien, R., Ufua, D., Moses, C. L., \& Osabuohien, E. (2020c). Accountability in agricultural governance and food security in Nigeria. Brazilian Journal of Food Technology, 23, e2019054. https://doi.org/10.1590/1981-6723.08919

Osabuohien, E. S., Okorie, U. E., \& Osabohien, R. A. (2018). Rice production and processingin Ogun State, Nigeria: qualitative insights from farmers' association. In Food Systems Sustainability and Environmental Policies in Modern Economies (pp. 188-215). IGI Global.

https://doi.org/10.4018/978-1-5225-3631-4.ch009

Phyo, A. (2018). The role of youth in agriculture and economic development, FFTC Agricultural Policy Outcome (FFTC-AP). Food and Fertilizer Technology Centre for the Asian and $\mathrm{Pa}-$ cific. http://ap.fftc.agnet.org/ap_db.php

Pye-Smith, C. (2012). Increasing rural employment in sub-Saharan Africa. CTA Policy Brief 4. www.cta.int

Samson, M., Nyokangi, E., Yang, M., Estruch, E., \& Rapone, C. (2015). Social protection and Agricultural Development: Transformational approaches to strengthening the decent work agenda. FAO, forthcoming.

Save the Children. (2009). How cash transfers can improve the nutrition of the poorest children. Evaluation of a safety net project in southern Niger.

Slater, R., \& McCord, A. (2009). Social protection, rural development and food security: Issues paper on the role of social protection in rural development. Overseas Development Institute.

Stavins, R. N., Wagner, A. F., \& Wagner, G. (2003). Interpreting sustainability in economic terms: dynamic efficiency plus intergenerational equity. Economics Letters, 79(3), 339-343. https://doi.org/10.1016/S0165-1765(03)00036-3

Stiglitz, J. E. (2012). The price of inequality: How today's divided society endangers our future. WW Norton \& Company.

Stringham, E. P. (2001). Kaldor-Hicks efficiency and the problem of central planning. Quarterly Journal of Austrian Economics, 4(2), 41-50.

The Food and Agriculture Organisation - FAO. (2015). The state of food and agriculture, Social protection and agriculture: breaking the cycle of rural poverty. Food and Agriculture Organisation, Rome.

Todd, J. E., Winters, P. C., \& Hertz, T. (2009). Conditional cash transfers and agricultural production: Lessons from the Oportunidades experience in Mexico. Journal of Development Studies, 46(1), 39-67. https://doi.org/10.1080/00220380903197945

Tirivayi, N., Knowles, M., \& Davis, B. (2013). The interaction between social protection and agriculture: A review of evidence. Food and Agriculture Organisation, Rome.

Van Kesteren, J. (2016). Assessing the risk and prevalence of hate crime victimization in Western Europe. International Review of Victimology, 22(2), 139-160. https://doi.org/10.1177/0269758015627046 